\title{
HUKUM EKONOMI BERKEADILAN SUBSTANTIF MENCIPTAKAN PEMBANGUNAN BERKELANJUTAN (SUSTAINABLE DEVELOPMENT)
}

\author{
Afrinald Rizhan \\ Program Studi Ilmu Hukum, Fakultas Ilmu Sosial, Universitas Islam Kuantan Singingi, Indonesia \\ afrinaldrizhan@gmail.com
}

\begin{abstract}
Abstrak
Keadaan perekonomian suatu negara sangat dipengaruhi oleh hukum yang ada di negara tersebut. Hal ini menjadi suatu hal yang saling terkait dan tidak dapat di pisahkan satu sama lain. Mengingat pertumbuhan ekonomi tersebut membutuhkan suatu batasan-batasan dalam pergerakkannya. Agar perekonomian itu dapat merata untuk kesejahteraan masyarakat atau bangsa, maka diharapkan peraturan-peraturan yang di buat oleh Pejabat yang berwenang mampu melahirkan peraturanperaturan yang bersikap adil. Di sinilah kita membutuhkan suatu ilmu hukum ekonomi guna mewujudkan visi bangsa Indonesia yang termaktub dalam pembukaan Undang-Undang Dasar 1945, yaitu "Memajukan Kesejahteraan Umum". Misinya adalah tugas yang diemban untuk menciptakan kehidupan yang ideal baik dalam arti spiritual maupun fisik materil.

Kata Kunci: hukum, negara, perekonomian berkelanjutan, keadilan substantive.
\end{abstract}

\begin{abstract}
Abstrack
The state of a country's economy is strongly influenced by the laws of that country. This becomes an interrelated matter and can not be separated from each other. Given that economic growth requires a limit in the movement. In order for the economy to be equitable for the welfare of the community or the nation, it is expected that the regulations made by the Authorized Officials capable of giving birth to rules that are fair. This is where we need a science of economic law in order to realize the vision of the Indonesian nation embodied in the preamble of the 1945 Constitution, namely "Promoting Public Welfare". Its mission is the task that is carried out to create an ideal life both in the spiritual and physical sense of the material.

Keywords: law, state, sustainable economy, substantive justice.
\end{abstract}




\section{PENDAHULUAN}

Dalam pergaulan dan interaksi suatu masyarakat sosial membutuhkan suatu peraturan-peraturan yang harus di taati mengingat norma-norma yang berlaku dalam masyarakat telah melekat sejak lingkungan sosial masyarakat itu terbentuk. Jadi, tidak hanya terangkum dalam norma hukum, tetapi juga terikat pada norma agama, norma kesusilaan, dan norma kesopanan. Hukum merupakan sesuatu yang berkenaan dengan manusia. Manusia dalam hubungannya dengan manusia lainnya dalam suatu pergaulan hidup. Tanpa pergaulan hidup (masyarakat) tidak akan ada hukum (ibi societas ibi ius zoon politicon). Hukum berfungsi mengatur hubungan pergaulan antarmanusia. Namun, tidak semua perbuatan manusia itu memperoleh pengaturannya. Hanya perbuatan atau tingkah laku yang diklasifikasikan sebagai perbuatan hukum saja yang menjadi perhatiannya (Rasjidi dan Rasjidi, 2007: 10).

Dalam konsepnya yang paling klasik (dalam pemikiran maupun dalam praktik) hukum per definisi adalah seperangkat norma moral-sosial. Apa yang disebut "hukum" itu adalah realitas yang eksis di alam sollen dengan posisinya yang a priori di hadapan segala bentuk perilaku manusia di alam pengalaman. Hukum adalah realitas kodrati, bagian dari keniscayaan alami yang tertanamkan dengan kekuatannya yang universal di dalam setiap idea dan budi nurani manusia, tanpa dapat di elakkan oleh manusia itu sendiri. Hukum menurut logikanya yang normatif seperti ini lalu senantiasa, dan niscaya pula, harus dipandang sebagai sesuatu realitas kodrati yang internal, sudah tertanam di dalam sanubari yang merupakan bagian integral eksistensi manusia, dan yang karena itu pula niscaya sudah eksis sebelum perilaku hukum manusia diwujudkan di alam pengalaman yang nyata. Dalam posisi yang logis-normatif seperti itu hukum adalah pengarah atau pengontrol atau pula tolok guna menilai benar salahnya setiap bentuk perilaku manusia (Wignjosoebroto, 2002: 180).

Menurut Plato, hukum adalah sistem aturan-aturan positif yang terorganisir atau terformulasi, mengikat pada keseluruhan individu dalam Negara (Bakir, 2007: 175). Hakikat hukum adalah keadilan. Hukum berfungsi melayani kebutuhan keadilan dalam masyarakat. Hukum menunjuk pada suatu aturan hidup yang sesuai dengan cita-cita tentang hidup 
bersama, yakni keadilan. Isi kaidah hukum, harusnya adil. Tanpa keadilan, hukum hanya merupakan kekerasan yang diformalkan (Tanya, Simajuntak, dan Hage, 2010: 219)

Hukum sebagai kategori moral serupa dengan keadilan, pernyataan yang ditujukan untuk pengelompokan sosial tersebut sepenuhnya benar, yang sepenuhnya mencapai tujuannya dengan memuaskan semua. Rindu akan keadilan, yang dianggap secara psikologis, adalah kerinduan abadi manusia akan kebahagiaan, yang tidak bisa ditemukannya sebagai seorang individu dan karenanya mencarinya dalam masyarakat. Kebahagiaan sosial dinamakan keadilan (Kelsen, 2009: 48).

Hukum ekonomi adalah suatu hubungan sebab akibat atau pertalian peristiwa ekonomi yang saling berhubungan satu dengan yang lain dalam kehidupan ekonomi seharihari dalam masyarakat. Sementara itu, keadilan substantif (keadilan substansial) adalah keadilan yang diberikan sesuai dengan aturan-aturan hukum substantis, tanpa melihat kesalahan-kesalahan prosedural yang tidak berpengaruh pada hak-hak substantif Penggugat/Pemohon. Ini berarti bahwa apa yang secara formal-prosedural benar bisa saja disalahkan secara materiil dan substansinya melanggar keadilan. Demikian sebaliknya, apa yang secara formal salah bisa saja dibenarkan. Jika secara materiil dan substansinya sudah cukup adil (hakim dapat menoleransi pelanggaran prosedural asalkan tidak melanggar substansi keadilan). Dengan kata lain, keadilan substantif bukan berarti hakim harus selalu mengabaikan bunyi undang-undang. Melainkan, dengan keadilan substantif berarti hakim bisa mengabaikan undang-undang yang tidak memberi rasa keadilan, tetapi tetap berpedoman pada formal prosedural.

Keadaan perekonomian suatu negara sangat dipengaruhi oleh hukum yang ada di negara tersebut. Hal ini menjadi suatu hal yang saling terkait dan tidak dapat di pisahkan satu sama lain. Mengingat pertumbuhan ekonomi tersebut membutuhkan suatu batasan-batasan dalam pergerakkannya. Agar perekonomian itu dapat merata untuk kesejahteraan masyarakat atau bangsa, maka diharapkan peraturan-peraturan yang di buat oleh Pejabat yang berwenang mampu melahirkan peraturan-peraturan yang bersikap adil. Di sinilah kita membutuhkan suatu ilmu hukum ekonomi guna mewujudkan visi bangsa Indonesia yang termaktub dalam pembukaan Undang-Undang Dasar 1945, yaitu “Memajukan Kesejahteraan Umum”. Misinya adalah tugas yang diemban untuk menciptakan kehidupan yang ideal baik dalam arti spiritual maupun fisik materiel (Arto, 2001: 11). 
Hanya saja saat ini kondisi perekonomian negara Indonesia terkesan amburadul, karena terjadi tumpang tindih kekayaan materi tiap-tiap masyarakat yang mana setiap tahunnya angka pengangguran semakin meningkat dan angka kemiskinan semakin tinggi. Akan tetapi, yang kaya masih saja tetap kaya dan berjaya. Hal ini tidak hanya membuktikan bahwa perekonomian negara Indonesia sudah gagal, tetapi juga hukum di Indonesia juga telah gagal.

Selain moral dan etika yang sudah tidak lagi sesuai dengan norma-norma yang berlaku, keadaan alam yang subur makmur pun turut mengalami perubahan yang sangat riskan. Mengingat maraknya pembukaan lahan dengan membakar hutan demi pembangunan, serta pengaruh globalisasi yang menciptakan global worming di Bumi ini. Disinilah kita membutuhkan suatu kebijakan atau aturan demi pembangunan yang lebih baik di masa yang akan datang.

Dari latar belakang yang telah diuraikan di atas, maka penulis memberi judul pada penelitian ini yaitu: "Hukum Ekonomi Berkeadilan Substantif Menciptakan Pembangunan Berkelanjutan (Sustainable Development)". Berdasarkan uraian latar belakang masalah tersebut, maka penulis merumuskan permasalahannya sebagai berikut: Bagaimanakah hukum ekonomi berkeadilan substantif menciptakan pembangunan berkelanjutan (sustainable development)

\section{METODE PENELITIAN}

Jenis penelitian/ pendekatan yang digunakan oleh penulis adalah penelitian hukum normatif yaitu penelitian hukum kepustakaan, karena menjadikan bahan kepustakaan sebagai tumpuan utama. Dalam penelitian hukum normatif ini penulis melakukan penelitian terhadap asas-asas hukum yang bertitik tolak dari bidang-bidang tata hukum tertentu, dengan cara mengadakan identifikasi terlebih dahulu terhadap kaidah-kaidah hukum yang telah dirumuskan di dalam perundang-undangan tertentu.

Sebagai pendukung, penelitian ini juga menggunakan pendakatan empiris yaitu mendapatkan informasi yang akurat dengan cara mengadakan identifikasi hukum dan bagaimana efektifitas hukum itu berlaku dalam masyarakat.

Dalam konsep normatif, hukum adalah norma, baik yang diidentikkan dengan keadilan yang harus diwujudkan (ius constituendum) ataupun norma yang telah terwujud sebagai perintah yang eksplisit dan yang secara positif telah terumus jelas (ius constitutum) 
untuk menjamin kepastiannya, dan juga berupa norma-norma yang merupakan produk dari seorang hakim (judgements) pada waktu hakim memutuskan suatu perkara dengan memperhatikan terwujudnya kemanfaatan dan kemaslahatan bagi para pihak yang berperkara. Sedangkan dilihat dari sifatnya penelitian ini bersifat deskriptif analisis.

\section{HASIL DAN PEMBAHASAN}

\section{HUKUM EKONOMI}

Hukum mempunyai tugas untuk menjamin adanya kepastian hukum dalam masyarakat. Oleh karena itu setiap masyarakat berhak untuk mendapat pembelaan di depan sehingga dapat diartikan bahwa hukum adalah peraturanm atau ketentuan-ketentuan tertulis maupun tidak tertulis yang mengatur kehidupamn masyarakat dan menyediakan sanksi bagi yang melanggar peraturan yang dibuat oleh Pejabat yang berwenang.

Hukum memiliki makna yang begitu luas jika dilihat dari berbagai sudut yang berlainan dan titik beratnya. Berikut ini adalah pandangan mengenai pengertian hukum dari para ahli sarjana hukum (dalam Antoni, 2010):

\section{1.) Menurut Van Kan}

Hukum merupakan keseluruhan peraturan hidup yang bersifat memaksa untuk melindungi kepentingan manusia di dalam masyarakat.

2.) Menurut Utrecht

Hukum merupakan himpunan peraturan (baik berupa perintah maupun larangan) yang mengatur tata tertib dalam suatu masyarakat dan seharusnya ditaati oleh anggota masyarakat yang bersangkutan. Oleh karena itu pelanggaran petunjuk hidup tersebut dapat menimbulkan tindakan dari pihak pemerintah.

3.) Menurut Wiryono Kusumo

Hukum adalah merupakan keseluruhan peraturan baik yang tertulis maupun tidak tertulis yang mengatur tata tertib di dalam masyarakat dan terhadap pelanggarnya umumnya dikenakan sanksi. Dari beberapa pendapat diatas dapat Saya simpulkan bahwa hukum memiliki makna yang luas meliputi semua peraturan atau ketentuan tertulis maupun tidak tertulis yang mengatur kehidupan masyarakat dan menyediakan sanksi terhadap pelanggarnya.

Ilmu ekonomi berasal dari bahasa Yunani, oikos dan nomos. Oikos yang artinya rumah tangga dan Nomos yang berarti aturan. Jadi ilmu ekonomi merupakan ilmu yang 
mempelajari bagaimana manusia mengelola sumber daya yang terbatas untuk memenuhi sumber daya yang terbatas. Hukum ekonomi adalah suatu hubungan sebab akibat atau pertalian peristiwa ekonomi yang saling berhubungan satu dengan yang lain dalam kehidupan ekonomi sehari-hari dalam masyarakat.

Hukum ekonomi terbagi menjadi 2, yaitu (dalam Didit, 2010):

a.) Hukum ekonomi pembangunan, yaitu seluruh peraturan dan pemikiran hukum mengenai cara-cara peningkatan dan pengembangan kehidupan ekonomi (misal hukum perusahaan dan hukum penanaman modal), dan

b.) Hukum ekonomi sosial, yaitu seluruh peraturan dan pemikiran hukum mengenai cara-cara pembagian hasil pembangunan ekonomi secara adil dan merata, sesuai dengan hak asasi manusia (misal, hukum perburuhan dan hukum perumahan).

\section{KEADILAN SUBSTANTIF}

Keadilan secara umum diartikan sebagai perbuatan atau perlakuan yang adil. Sementara adil adalah tidak berat sebelah, tidak memihak dan berpihak kepada yang benar. Keadilan menurut kajian filsafat adalah apabila dipenuhi dua prinsip, yaitu : pertama, tidak merugikan seseorang dan kedua, perlakuan kepada tiap-tiap manusia apa yang menjadi haknya. Jika kedua prinsip ini dapat dipenuhi barulah itu dikatakan adil.

Keadilan merupakan tujuan hukum yang utama karena hanya dengan keadilan tatanan kehidupan masyarakat bisa terpelihara. Supremasi hukum adalah upaya untuk memberikan jaminan terciptanya keadilan. Keadilan harus diposisikan secara netral, artinya setiap orang memiliki kedudukan dan perlakuan yang sama dihadapan hukum (equality before the law).

Keadilan subtantif merupakan keadilan yang lebih memandang kepada unsur kemanusiaan di mana manusia itu bermukim, sedangkan Supermasi Hukum adalah adanya upaya memberikan jaminan keadilan secara netral, tidak memandang kelas, tingkatan ataupun golongan dalam masyarakat. Dua pilar ini merupakan sesuatu yang penting di dalam membangun masyarakat Madani. Sebab, masyrakat madani adalah masyarakat di mana suatu negara antara pemerintah dan rakyat dapat hidup secara berdampingan, bekerjasama demi terciptannya kepastian hukum, keadilan yang nyata serta keseimbangan antara hak dan kewajiban. 


\section{PEMBANGUNAN BERKELANJUTAN (SUSTAINABLE DEVELOPMENT)}

Pembangunan berkelanjutan masih berada pada tataran konsep. Neuman dan Sarantakos (dalam Indarti, 2000), menyebutkan bahwa konsep merupakan blok-blok dasar yang menyusun suatu teori. Selanjutnya dikatakannya, konsep mengandung asumsi secara built-in yakni pernyataan mengenai sifat (dan ciri-ciri) berbagai hal yang tidak atau belum diobservasi maupun di test. Apabila Pembangunan Berkelanjutan mengandung asumsiasumsi berbagai hal menyangkut environmental awareness sebagaimana disebut di atas.

Prinsip-prinsip yang terkandung dalam konsep Pembangunan Berkelanjutan dikemukakan secara lebih rinci dalam Deklarasi dan Perjanjian Internasional yang dihasilkan melalui Konferensi PBB tentang Lingkungan dan Pembangunan (United Nations Conference on Environment and Development) di Rio de Janiero pada tahun 1992. Dari berbagai dokumen yang dihasilkan pada Konferensi itu, secara formal terdapat 5 (lima) prinsip utama dari pembangunan berkelanjutan yaitu (Santosa, 1996):

1. Prinsip keadilan antar generasi (intergenerational equity);

2. Prinsip keadilan dalam satu generasi (intragenerational equity);

3. Prinsip pencegahan dini (precautionary);

4. Prinsip perlindungan keragaman hayati (conservation of biological diversity); dan

5. Prinsip internalisasi beaya lingkungan.

Di bawah ini diuraikan secara garis besar isi dari prinsip-prinsip tersebut (Samekto, 2008):

a. Prinsip Keadilan Antar Generasi

Prinsip ini mengandung makna bahwa setiap generasi umat manusia di dunia memiliki hak untuk menerima dan menempati bumi bukan dalam kondisi yang buruk akibat perbuatan generasi sebelumnya.

b. Prinsip Keadilan Dalam Satu Generasi

Prinsip keadilan dalam satu generasi (intragenerational equity) merupakan prinsip yang berbicara tentang keadilan di dalam sebuah generasi umat manusia, dimana beban dari permasalahan lingkungan harus dipikul bersama oleh masyarakat dalam satu generasi.

c. Prinsip Pencegahan Dini

Prinsip pencegahan dini (precautionary principle) mengandung suatu pengertian bahwa apabila terdapat ancaman yang berarti, atau adanya ancaman kerusakan lingkungan yang tidak dapat dipulihkan, ketiadaan temuan atau pembuktian ilmiah yang konklusif dan 
pasti, tidak dapat dijadikan alasan untuk menunda upaya-upaya untuk mencegah terjadinya kerusakan lingkungan.

d. Prinsip Perlindungan Keragaman Hayati

Perlindungan keragaman hayati merupakan prasyarat dari berhasil-tidaknya pelaksanaan prinsip keadilan antar generasi (intergenerational equity principle). Perlindungan keragaman hayati juga terkait dengan masalah pencegahan, sebab mencegah kepunahan jenis dari keragaman hayati diperlukan demi pencegahan dini.

e. Internalisasi Beaya Lingkungan

Kerusakan lingkungan dapat dilihat sebagai external cost dari suatu kegiatan ekonomi yang diderita oleh pihak yang tidak terlibat dalam kegiatan ekonomi tersebut. Jadi kerusakan lingkungan merupakan external cost yang harus ditanggung oleh pelaku kegiatan ekonomi. Oleh karena itu, beaya kerusakan lingkungan harus diintegrasikan ke dalam proses pengambilan keputusan yang berkaitan dengan penggunaan sumber-sumber alam tersebut.

Perkembangan perekonomian suatu negara yang saat ini dirasa telah memberikan hasil yang memilukan, yang mana angka pengangguran dan angka kemiskinan tiap tahunnya dirasa semakin meningkat. Tingkat kejahatan pun juga terpengaruhi oleh keadaan yang demikian. Mengingat maraknya perbuatan Korupsi Kolusi Nepotisme (KKN) dan juga Global Worming yang telah merusak keadaan alam negeri ini. Pembukaan lahan dengan cara membakar membuat alam terus dipengaruhi oleh polusi udara, serta mengganggu pertumbuhan flora dan fauna.

Sesuai dengan prinsip utama dari pembangunan berkelanjutan yang telah di konferensikan oleh PBB maka faktor lingkungan secara tidak langsung memberikan imbas kepada perekonomian. Karena alam adalah tempat dimana masyarakat berdomisili. Maka sudah selayaknya alam dan seisinya dapat dijaga kelestariannya untuk diwarisi kepada anak cucu kita nanti. Dari Sumber Daya Alam itulah salah satu sumber perkonomian negara, dan untuk menjaga agar alam atau lingkungan itu tidak tercemar maka kita membutuhkan suatu peraturan yang tegas. Disinilah peran serta keadilan yang bersifat substantif di butuhkan. Karena pada hakikatnya keadilan subtantif merupakan keadilan yang lebih memandang kepada unsur kemanusiaan di mana manusia itu bermukim. Dengan begitu, maka sudah semestinya kita menetapkan hukum ekonomi yang menerapkan keadilan substantif agar dapat 
menciptakan pembangunan yang berkelanjutan, efeknya adalah membentuk negara yang sejahtera (welfare state).

\section{KESIMPULAN}

Keadaan hukum di suatu negara akan mempengaruhi perkembangan atau pertumbuhan perekonomian negara tersebut. Bagaimana suatu peraturan atau kebijakan yang dibuat oleh Pemerintah negara mampu memberikan suatu batasan-batasan terhadap laju perekonomian. Tumpang tindih yang terjadi saat ini yang melahirkan golongan amat kaya dan golongan sangat miskin membuktikan kepada kita bahwa hukum belum mampu menjalankan fungsinya dengan baik. Terlebih keadaan lingkungan yang juga mempengaruhi laju perekonomian. Karena dari sumber daya alam lah salah satu hasil pendapatan suatu negara.

Ada beberapa hal yang dapat kita lakukan untuk memperbaiki kegagalan perekonomian tersebut salah satunya adalah menerapkan hukum ekonomi yang berkeadilan substantif, yakni keseimbangan dan pembagian proposional antara hak dan kewajiban yang didasarkan pada pemahaman dan perasaan keadilan di mana masyarakat itu bermukim.

Jadi solusi yang terbaik adalah, Pemerintah dapat membuat kebijakan mengenai hukum ekonomi yang menerapkan keadilan yang substantif agar dapat menciptakan pembangunan berkelanjutan, yang efeknya adalah mampu membentuk negara yang sejahtera (welfare state).

\section{DAFTAR PUSTAKA}

Arto, Mukti. (2001). Mencari Keadilan. Yogyakarta: Pustaka Pelajar.

Antoni, Benny. (2010). Pengertian Hukum dan Hukum Ekonomi. Di unduh dari http://bennyantoni.blogspot.com/2010/02/resume-bab-1-pengertian-hukum-danhukum.html tanggal 20 Januari 2019

Bakir, Herman. (2007). Filsafat Hukum Desain dan Arsitektur Kesejarahan. Bandung: Refika Aditama

Didit. (2010). Pengertian Hukum dan Hukum Ekonomi. Diunduh dari http://20208376didit.blogspot.com/2010/03/pengertian-hukum-dan-hukum-ekonomi.html tanggal 25 Januari 2019

Kelsen, Hans. (2009). Pengantar Teori Hukum. Bandung: Nusamedia. 
Tanya, L Bernard, N Simajuntak, dan Markus Y. Hage. (2010) Teori Hukum Strategi Tertib Manusia Lintas Ruang dan Generasi. Yoryakarta: Genta Publishing.

Rasjidi, Lili dan Ira Thania Rasjidi. (2007). Dasar-dasar Filsafat dan Teori Hukum. Bandung: Citra Aditya Bakti.

Samekto, Adji. (2008). Kapitalisme, Modernisasi, dan Kerusakan Lingkungan. Yogyakarta: Genta Press.

Wignjosoebroto, Soetandyo. (2002). Hukum Paradigma dan Dinamika Masalahnya. Jakarta: ELSAM HUMA

Santosa, Achmad. (1996). Aktualisasi Prinsip-Prinsip Pembangunan Berkelanjutan yang Berwawasan Lingkungan Dalam Sistem dan Praktek Hukum Nasional. Jurnal Hukum Lingkungan. Tahun III.

Indarti, Erlyn. (2000). Paradigma: Jati Diri Cendekia. Makalah disampaikan pada Diskusi Ilmiah Program Doktor Ilmu Hukum Universitas Diponegoro, Semarang, 1 Desember 2000 . 